\title{
TRANSLATIONS
}

\section{An excerpt from the English translation of Amrit Lal Nagar's Hindi novel Nachyo Bahut Gopal}

\section{Sheeba Rakesh}

Published in the year 1978, N(achyo)B(ahut) G(opal) brought with it a new wave-of literary and sociological consciousness. It talks about the problem of casteism in the Indian society, the ravages caused by the white ants of untouchability and the hollowness that has crept up in the wake of such an attack in the modern Indian society. $N B G$ is a story that moves on two levels: a) Gender and $b$ ) Caste and Class. It chronicles the life story of Smt. Nirguniya - a Brahmin woman. A blend of autobiography and reportage, the story relates her trials in the aftermath of her 'voluntary conversion' to Dalit way of life. Several social/psychological/philosophical questions have been answered by Nagar by making Smt. Nirguniya not a victim, but a stoic agent of social change who realizes that casteism is nothing but a farce and refuses to come back into the 'elite' mould of the Brahmin narrator (who is the author's mouthpiece), accepting her own achoot/ bhangi/ dalit identity with pride and integrity...

...The content and the form have achieved a perfect fusion in Nagar and this translation has tried the best to preserve this uniqueness which grants Nachyo Bahut Gopal a high place in the pantheon of Hindi literature... although literal translations have not been possible (and linguistic originality retained where essential) the translation has been an attempt at unraveling or more appropriately popularizing Nagar's art and aesthetics. It is hoped that the translation will be successful in its attempt.*

\footnotetext{
* extracts from Sheeba Rakesh's proposal for publication to Columbia
} University Press.

Translation Today Vol. 6 No. 1 \& 22009 (C) CIIL 2009 
She was counting the coins for the rickshawallah when I alighted. Elated on seeing me she said, “...I am so glad you have come, I knew you would..."

I paid my rickshawallah, picked her heavy bag and proceeded towards the verandah. Smt. Nirguniya said, “... I had an intuition that you would come today ... therefore came back ..."

She unlocked the door. There was an envelope lying inside. Her face blossomed as she read it, “...it's Shakun's... my daughter's...!!”

Instructing me to keep the bag in the inner room she continued to unlock the inner rooms. Sunlight had filled the inner sanctum of the house. She went and came back with a covered bowl, removed the lid and said, "...I brought this Nimish from the grain mandi... thought it would be a befitting gift for winter"

I asked, “...Where did you learn to speak Urdu...?”

She laughed, “...We have patrons in all religions... the one to help me out on my rainy days resided in a Muslim locality; but babuji!... generally bhangis do speak well..."

“...Please don't call me babuji...I feel ashamed..."

“...How else do I address you then...?"

"Call me Anshu...or maybe... Anshudhar..."

"...It is a sin to call Brahmins, kings and pundits by their names..."

“...I am hardly surprised at your wise repartees ...call me Sharma...”

“...How can a besharm woman call you ... Sharma! Sharma! ... it would make you feel sharm..." 
She laughed, but her eyes reflected intense pain. I struck the hot iron, "...Smt. Nirguniya!... what if you happen to meet somebody from your early life now...?"

"...but they must all be dead..."

“Answer...suppose your husband Aryaputra Masuriyadin...?"

“...my Mohna sent him to hell long back...ha! ha!...", she laughed a hard laugh.

“...Then maybe Chhote babu or Master Basantlal...?”

She contemptuously retorted, “...Nobody can harm a shameless woman ...these bastards were responsible for turning my body into a pot of shit...."

“...Chhote babu could be blamed, but as for master Basantlal or the others... you dirtied them... and you can't blame them..."

She was comfortably seated on the settee. Suddenly getting flustered by my taut remarks she got up, then turned to me and snatching a bidi from the bundle said, "...I am so ashamed that I feel like burying myself in the womb of the earth or atleast get drunk to the extent of tippling so that I may answer back... don't take it otherwise... I mean that's what I felt... so...! you were on... what if Chhote babu saw me like this?... so what? Infact, I happened to meet Master Basantlal once... but of that... I shall speak later... but in sharing my story with you... I had overcome all the guilt, sin as well as suffocation of my life... Today, I am happy being a bhangi ... I want to remain a bhangi... not a Brahmin anymore..."

I countered, “....was not your inner Brahmin attracted to me?... the temple of my house and your recitation of the sacred Sanskrit shlokas ...was this not an attempt at awaking the Brahmin within...??" 
Silence. The twitching of the face and an intense restlessness to hide behind a new façade - I should not have been so blunt. Staring at me, eye into eye, she spoke, “...I will not lie to you... yes!... you are right..."

Her acknowledgement encouraged my bluntness. Had $I$ been questioned like this, my ego too would have run amuck to save its face... just like Smt. Nirguniya... after all... every human being tries to protect his ego. I continued, “....How did you feel as Smt. Mohna?... A bhangin venturing into the bylanes with a tokra of dirt and shit...?"

“...I get your question... working as a bhangin among the Brahmins was shameful to me... but I never felt like disclosing my antecedents to any of them..."

"...How then could you do it with me...?"

“...That's an easy question ...let me take out my tharra... I want to be shameless now..." She went ahead and opened an almirah full of desi and foreign liquor bottles. Old Scotch. She got some glasses and water, “...This bottle is forty years old... My Shakun's first birthday... Mohna was wanted by the police... but he was a courageous father... came as a bhangi to see his Shakuntala... Jhaadu and tokra... he managed to ditch the authorities... brought two whisky bottles, mithai, toys... In all these years I never touched it more than twice... the last time I had it was with him...!" Her emotional trance seemed to turn the bottle into Mohna for her.

I questioned, “...so you only drink this, when trapped in dire situations...?"

"...Yes... your questions make my heart sink... have some..."

Politely declining the offer I continued to question her on her emotional state when she must have gone as a bhangi to the Brahmin houses.

She said, “...Initially, I felt like chopping off my own neck... I could not stand to do this... but then I read Kabir... 
Sees kaat bhuin maa dhare,

Taa par raakhe paawn...

So ultimately, I did cut off my head and placed my foot on it. Brahmin and chamar ... where was the difference? ...everyone was a patron... I never thought of it this way... and today in front of you...

She seemed to gaze into eternity. Lighting a cigarette I asked, “...but why before me?... I look like an average Indian... not a tripunddhari pundit"

She seemed to have been caught by the 'enchanted by Mohna' mood and spoke, “...your Brahmanism was secondary... I was impressed by your interest in the bhangi community, culture and lifestyle... that sent me into thinking about the reality of my own caste!... who indeed was I...? ... Chamars have innumerable castes and sub-castes... whose rituals did I follow?... do I tell you about the caste of my birth or the caste of my karma? ...perhaps, this would not have mattered much if you had not persisted in meeting me ...eventually, the human connection that we established resurrected my inner Brahmin .... and that is why an urge to enact a psyche striptease before you... babuji! This glass of liquor is Gangajal to me... and I will not lie... you are an extraordinary human being... and that is why I felt like unburdening myself..."

A suggestive tone, facility of dialogue and the appropriate texture of tested and defeated character - a bhangin had amalgamated all the essential ingredients to touch my Brahmin soul. Silence again. I broke it, "...I am curious about your past... give me the file..."

Smiling and holding her magnetic gaze steady she said, “...I have written a lot... but it is all in bits and pieces...recollections and strewn expressions...."

“...Oh! You've left me stranded in a mirage... why don't you write an autobiography...?"

“...I feel tired...since the last two years...I have not touched the pen...." 
"... was it because you expressed only the bitter experiences of your life...?"

"...No babuji!... but the urge for expression has waned ..."

“...How did you feel with Masuriyadin...?”

"...It was weird...like craving for satisfaction in heat and being denied ...."

"I understand! ...the need must have driven you mad...."

“...suffice it to say that I was kept under lock and key ...haraami! ...sorry babuji!... but, he did everything possible to avoid my meeting with other men ...had even locked the terrace door...denied me a chance for suicide... babuji! fate punished me hard... I suffered two births in one... and Oh! what an immeasurable pain!!...”

“...So you believe in fate ...?"

“...Can't say...man masters fate ...but I was not responsible for my mother's death...I was a good girl with sacred values but got a bitchy mother and a pimp-like father... had $I$ asked for it?... fate showed me the roads and I took them..."

Today I saw the real Smt. Nirguniya. Heat tempers gold. The heat of time had tempered her as well. She cooked and we talked... before I left I requested her to start writing about her life once again. She refused and asked me to put her life story into words.

What a strange thing!! ...can I peep into somebody's soul? But I think I have begun to understand her... and the evil star influencing her life. I started writing — that very night! 